\title{
Impact of Horticulture Development of Tribal Area Development Programme on Tribals of Udaipur District, India
}

\author{
Sonali Sharma ${ }^{1 *}$, Snehlata Maheshwari², Rajshree Upadhyay ${ }^{2}$, \\ Bhupendra Upadhyay ${ }^{3}$ and H.R. Sain ${ }^{4}$ \\ ${ }^{1}$ SMS (Home Science), KVK-Barmer (Raj.), India \\ ${ }^{2}$ Department of Home Science Extension and Communication Management, College of Home \\ Science MPUAT, Udaipur, India \\ ${ }^{3}$ Department of Statistics, Rajasthan College of Agriculture, MPUAT, Udaipur, India \\ ${ }^{4}$ SMS (Agri.Ext.), KVK-Barmer (Raj.), India \\ *Corresponding author
}

\section{A B S T R A C T}

Keywords

Horticulture Development,

Tribal Area,

Udaipur District

Article Info

Accepted:

18 April 2019

Available Online:

10 May 2019
The study was conducted in tribal area of Udaipur district where Tribal Area Development Programme is in operation under Tribal Area Development Department. The department implements the programme services through line departments or related organization in the area. The Agricultural services are intensively implemented in three tribal blocks namely Jadol, Sarada and Lasadiya as informed by the department personnel hence these three blocks were purposively selected for the study. There were six Agricultural services and for each service, two villages were selected for beneficiaries. According to the study findings it can be concluded that, majority of the beneficiaries possessed good or average knowledge and non-beneficiaries possessed average or poor knowledge in Agricultural Services viz. Horticulture Development and Development of whole (Agriculture) Tribal Villages. Adoption of Aonla cultivation practices reflects that beneficiaries had high extent of adoption in all the components. Regarding improvement in quality of life the beneficiaries of each Horticulture Development have improved significantly. (Key words:Tribal, Horticulture, Agricultural, Aonla etc.)

\section{Introduction}

The tribals form an integral part of India's social fabric and have second largest concentration of tribal population in the world after that of the African continent. Tribals are most primitive people living in isolation and constitute 8.61 per cent of the total population of the country, numbering 104,281,034 millions, out of which $93,819,162$ residing in 
rural area and 10,461,872 living in urban area. The country's 15 per cent of the total geographical area are covered by tribal population. They reside mainly in forests, hills and undulating inaccessible terrain in plateau areas, rich in natural resources (India census 2011).

Rajasthan, one of the most picturesque states of India, is widely known for its lakes, palaces, deserts and princely heritage and valor of men. Its wide range of climate and topography makes it a challenging area to live in, with the layout of tourist fascination, for culture and beauty of Rajasthan lies in the valuable tribal groups whose joys and hopes add brighter shades in places to otherwise gloomy but revealing portrait of tears and toils, suffering and sorrow of the people, who stand the shock of life, struggle in their way. The tribes of Rajasthan, as elsewhere in the country are passing through a process of socio-cultural and demographic transformation. Rajasthan is the largest state in the country having geographical area of $3,42,339$ sq. $\mathrm{km}$ or 10.41 per cent of the total geographical area of the country. The population of Rajasthan according to Census 2011 stands at about 68 million, making it the 8th most populated state in India, the population of Scheduled Tribe is 9,238,534, further in rural areas 8,693,123 tribal and 545,411 tribal in urban areas of the state, but the concentration of the ST population is greater in some parts of the state.

Attempts have been made to make the scheduled tribes to develop socially, educationally, economically, politically and culturally. For the development of tribes, various models, approaches and theories of development have been propounded in different five-year plan periods. In the Five Year Plans, the programmes for the welfare of the schedule tribes aim at: 1. raising the productivity levels in agriculture, animal husbandry, forestry, cottage and small- scale industries etc., to improve the economic conditions. 2. Rehabilitation of the bonded labours. 3. Education and training programmes. 4. Special development programmes for women and children. Though the efforts have been in the direction for development of tribal particularly with the creation of special multi-purpose tribal blocks during the second plan period however, a major break-through took place in the Fifth Five Year Plan in which a new strategy of tribal sub-plan for preparing micro plans for relatively valuable tribal groups requiring special attention was enunciated (Jatana and Waldia, 2009). But various evaluation studies on these programmes for the integrated development of the tribals have brought out the inadequacies of those programmes. Horticulture Development Programme is the Agricultural service provided under Tribal Area Developmental Programme (TADP) through special central assistance. Horticulture Development Programme is the programme in which tribals grow aonla. The aonla fruit (the Indian gooseberry) (Emblica officinalis G.) is one of the richest sources of Vitamin C. It contains 500 to $700 \mathrm{mg}$ of ascorbic acid per $100 \mathrm{~g}$ of pulp. This is much more than the vitamin $\mathrm{C}$ content of guava, tomato or citrus fruits.

Aonla is an ancient fruit of Indian origin, which is associated with our tradition, culture and heritage. The fruit is also closely connected with Indian system of medicine, as it is used as an ingredient in more than 175 formulations of Ayurveda. It is an important ingredient of Triphala and Chavanprash in ayurvedic medicine system. Fruits are commonly used for preserve (murabbas), pickles, candy, jelly, jam etc. It is a great health and vitality restorer. The fruit is useful in haemorrhages, diarrhoea, dysentry, anemia, jaundice, dyspepsia and cough (Gondalia et al., 2007). 
Aonla has great tolerance to salinity, alkalinity and sodicity. About its ability to stand drought conditions, it can be said as if nature has created this plant only for drought conditions. Aonla is a deciduous fruit tree. In this crop flower and fruit set take place in spring in February and soon after the fruits enter dormancy without any growth throughout the summer till monsoon. Therefore, plants do not require irrigation during summer when most crops would require it. With the onset of monsoon, the fruit starts growing and becomes ready for harvest by December. This is the most ideal crop for arid conditions.

\section{Materials and Methods}

The study was conducted in tribal area of Udaipur district where Tribal Area Development Programme is in operation under Tribal Area Development Department. The department implements the programme services through line departments or related organization in the area. The Agricultural services are intensively implemented in three tribal blocks namely Jadol, Sarada and Lasadiya as informed by the department personnel hence these three blocks were purposively selected for the study. There were six Agricultural services and for each service, two villages were selected for beneficiaries. Thus 12 villages were selected for beneficiaries for each service, thirty beneficiaries (15 from each village) were selected randomly, making a total sample of 180 beneficiaries for the six Agricultural services. The interview schedule was developed by the researcher after extensive review of literature and in consultation with the subject matter specialists from the concerned department/organization. The personal interview method was used by the researcher for the purpose of data collection. Informal observations were also made to check the information regarding adoption of practices. For statistical analysis frequency, percentage, Mean Percent Scores (MPS), Mean Weighted Scores (MWS) and Students' ' $t$ ' test were used.

\section{Results and Discussion}

\section{Knowledge regarding Horticulture Development Service}

In Horticulture Development service, improved practices related to aonla cultivation were promoted in the study area. Hence the information was collected about aonla cultivation practices and presented in Table 1. Data in the table shows that the overall knowledge of beneficiaries in improved aonla cultivation was found to be good with MPS 80.08 and of the non-beneficiaries average with MPS 47.94. This is also evident from the distribution of respondents as all the beneficiaries were in good knowledge category while majority of the nonbeneficiaries $(93.33 \%)$ were in average knowledge category.

The table further reveals that in all the components (except one) of aonla cultivation majority of the beneficiaries were falling in good knowledge category along with the MPS values viz. soil and climate (91.11 MPS), propagation (71.66 MPS), plantation (84.76 MPS), training (73.33 MPS), manure and fertilizer application (84.16 MPS), plant protection measures (70.33 MPS), irrigation (100 MPS) and harvesting, post harvesting and marketing (90.83 MPS) only in the component of high yielding varieties where half beneficiaries $(50 \%)$ were falling in average knowledge category and 43.33 per cent beneficiaries had good knowledge with MPS 64.16 depicting average knowledge.

However in case of non-beneficiaries 20 - 60 per cent were in the average knowledge category, 16 - 70 per cent in poor knowledge category and 3.33 - 56.66 per cent in good 
knowledge category, also reflected by average knowledge in MPS (38.33 - 60) possessed by the non - beneficiaries in various components of aonla cultivation.

The difference in beneficiaries and nonbeneficiaries knowledge might be due to the specific information possessed by beneficiaries related to aonla cultivation practices such as high yielding varieties, their advantages, suitable climate and specific time of cultivation, sowing and propagation time, recommended age and length of saplings to transplant, distance between rows and plants, pit size, amount of manure and fertilizers to be filled, training, plant protection, irrigation measures, harvesting and marketing.

Adoption of horticulture development service

Improved cultivation practices of aonla were emphasized in Horticulture Development programme. Adoption of improved cultivation practices of aonla was studied and presented in Table 2.

Table.1 Distribution of the respondents by the knowledge regarding improved Practices of aonla cultivation

\begin{tabular}{|c|c|c|c|c|c|c|c|c|c|}
\hline \multirow{4}{*}{$\begin{array}{l}\text { S. } \\
\text { No }\end{array}$} & \multirow{4}{*}{ Components } & & & & & & & & $\mathrm{n}=60$ \\
\hline & & \multicolumn{8}{|c|}{ Knowledge } \\
\hline & & \multicolumn{4}{|c|}{$\begin{array}{c}\text { Beneficiaries } n_{1}=30 \\
\mathbf{f}(\%)\end{array}$} & \multicolumn{4}{|c|}{$\begin{array}{c}\text { Non - Beneficiaries } n_{2}=30 \\
\mathbf{f}(\%)\end{array}$} \\
\hline & & Good & Average & Poor & MPS & Good & Average & Poor & MPS \\
\hline 1 & $\begin{array}{l}\text { High yielding } \\
\text { Varieties }\end{array}$ & $\begin{array}{c}13 \\
(43.33)\end{array}$ & $\begin{array}{c}15 \\
(50)\end{array}$ & $\begin{array}{c}2 \\
(6.66)\end{array}$ & 64.16 & $\begin{array}{c}4 \\
(13.33)\end{array}$ & $\begin{array}{c}14 \\
(46.66)\end{array}$ & $\begin{array}{c}12 \\
(40)\end{array}$ & 38.33 \\
\hline 2 & Soil \& Climate & $\begin{array}{c}23 \\
(76.66)\end{array}$ & $\begin{array}{c}6 \\
(20)\end{array}$ & $\begin{array}{c}1 \\
(3.33)\end{array}$ & 91.11 & $\begin{array}{c}6 \\
(20)\end{array}$ & $\begin{array}{c}13 \\
(43.33)\end{array}$ & $\begin{array}{c}14 \\
(46.66)\end{array}$ & 60 \\
\hline 3 & Propagation & $\begin{array}{c}13 \\
(46.66)\end{array}$ & $\begin{array}{c}17 \\
(56.66)\end{array}$ & 0 & 71.66 & $\begin{array}{c}1 \\
(3.33)\end{array}$ & $\begin{array}{c}8 \\
(26.66)\end{array}$ & $\begin{array}{c}21 \\
(70)\end{array}$ & 38.33 \\
\hline 4 & Plantation & $\begin{array}{l}27 \\
(90)\end{array}$ & $\begin{array}{c}3 \\
(10)\end{array}$ & 0 & 84.76 & $\begin{array}{c}7 \\
(23.33)\end{array}$ & $\begin{array}{c}18 \\
(60)\end{array}$ & $\begin{array}{c}5 \\
(16.66)\end{array}$ & 50.95 \\
\hline 5 & Training & $\begin{array}{c}14 \\
(46.66)\end{array}$ & $\begin{array}{c}16 \\
(53.33)\end{array}$ & 0 & 73.33 & $\begin{array}{c}5 \\
(16.66)\end{array}$ & $\begin{array}{c}18 \\
(60)\end{array}$ & $\begin{array}{c}7 \\
(23.33)\end{array}$ & 46.66 \\
\hline 6 & $\begin{array}{l}\text { Manure \& } \\
\text { Fertilizers }\end{array}$ & $\begin{array}{c}25 \\
(83.33)\end{array}$ & $\begin{array}{c}5 \\
(16.66)\end{array}$ & 0 & 84.16 & $\begin{array}{c}13 \\
(43.33)\end{array}$ & $\begin{array}{c}6 \\
(20)\end{array}$ & $\begin{array}{c}11 \\
(36.66)\end{array}$ & 53.33 \\
\hline 7 & $\begin{array}{l}\text { Plant } \\
\text { Protection } \\
\text { Measures }\end{array}$ & $\begin{array}{c}17 \\
(56.66)\end{array}$ & $\begin{array}{c}10 \\
(33.33)\end{array}$ & $\begin{array}{c}3 \\
(10)\end{array}$ & 70.33 & $\begin{array}{c}4 \\
(13.33)\end{array}$ & $\begin{array}{c}12 \\
(40)\end{array}$ & $\begin{array}{c}14 \\
(46.66)\end{array}$ & 40 \\
\hline 8 & Irrigation & $\begin{array}{c}30 \\
(100)\end{array}$ & 0 & 0 & 100 & $\begin{array}{c}12 \\
(40)\end{array}$ & $\begin{array}{c}10 \\
(33.33)\end{array}$ & $\begin{array}{c}8 \\
(26.66)\end{array}$ & 56.66 \\
\hline 9 & $\begin{array}{l}\text { Harvesting, } \\
\text { Post } \\
\text { Harvesting \& } \\
\text { marketing }\end{array}$ & $\begin{array}{c}30 \\
(100)\end{array}$ & 0 & 0 & 90.83 & $\begin{array}{c}17 \\
(56.66)\end{array}$ & $\begin{array}{c}13 \\
(43.33)\end{array}$ & 0 & 52.5 \\
\hline \multicolumn{2}{|c|}{ Over all } & $\begin{array}{c}30 \\
(100)\end{array}$ & $\mathbf{0}$ & $\mathbf{0}$ & 80.08 & $\begin{array}{c}2 \\
(6.66)\end{array}$ & $\begin{array}{c}28 \\
(\mathbf{9 3 . 3 3})\end{array}$ & $\mathbf{0}$ & 47.94 \\
\hline
\end{tabular}


Table.2 Distribution of the respondents by the adoption of improved Practices of aonla cultivation

\begin{tabular}{|c|c|c|c|c|c|c|c|c|c|}
\hline \multirow{4}{*}{$\begin{array}{c}\text { S. } \\
\text { No }\end{array}$} & \multirow{4}{*}{ Components } & \multirow{2}{*}{\multicolumn{8}{|c|}{ Extent of adoption }} \\
\hline & & & & & & & & & \\
\hline & & \multicolumn{4}{|c|}{$\begin{array}{c}\text { Beneficiaries } \mathbf{n}_{1}=30 \\
\mathbf{f}(\%)\end{array}$} & \multicolumn{4}{|c|}{$\begin{array}{c}\text { Non }- \text { Beneficiaries } \mathbf{n}_{2}=\mathbf{3 0} \\
\mathbf{f}(\%)\end{array}$} \\
\hline & & High & Medium & Low & MPS & High & Medium & Low & MPS \\
\hline 1 & $\begin{array}{l}\text { High yielding } \\
\text { Variety }\end{array}$ & $\begin{array}{c}30 \\
(100)\end{array}$ & 0 & 0 & 100 & $\begin{array}{c}13 \\
(43.33)\end{array}$ & $\begin{array}{c}7 \\
(23.33)\end{array}$ & $\begin{array}{c}10 \\
(33.33)\end{array}$ & 55 \\
\hline 2 & $\begin{array}{l}\text { Type of soil used } \\
\text { for cultivation }\end{array}$ & $\begin{array}{c}30 \\
(100)\end{array}$ & 0 & 0 & 100 & $\begin{array}{c}9 \\
(30)\end{array}$ & $\begin{array}{c}9 \\
(30)\end{array}$ & $\begin{array}{c}21 \\
(70)\end{array}$ & 38 \\
\hline 3 & Propagation & $\begin{array}{c}24 \\
(80)\end{array}$ & $\begin{array}{c}6 \\
(20)\end{array}$ & 0 & 90 & $\begin{array}{c}10 \\
(33.33)\end{array}$ & $\begin{array}{c}14 \\
(46.66)\end{array}$ & $\begin{array}{c}6 \\
(20)\end{array}$ & 57 \\
\hline 4 & Sowing time & $\begin{array}{c}27 \\
(90)\end{array}$ & $\begin{array}{c}3 \\
(10)\end{array}$ & 0 & 95 & $\begin{array}{c}18 \\
(60)\end{array}$ & $\begin{array}{c}7 \\
(23.33)\end{array}$ & $\begin{array}{c}5 \\
(16.66)\end{array}$ & 72 \\
\hline 5 & Pit size & $\begin{array}{c}21 \\
(70)\end{array}$ & $\begin{array}{c}4 \\
(13.33)\end{array}$ & $\begin{array}{c}5 \\
(16.66)\end{array}$ & 76.66 & $\begin{array}{c}12 \\
(40)\end{array}$ & $\begin{array}{c}5 \\
(16.66)\end{array}$ & $\begin{array}{c}13 \\
(43.33)\end{array}$ & 48 \\
\hline 6 & $\begin{array}{l}\text { Manure and } \\
\text { fertilizers filled in } \\
\text { pits }\end{array}$ & $\begin{array}{c}19 \\
(63.33)\end{array}$ & $\begin{array}{c}8 \\
(26.66)\end{array}$ & $\begin{array}{c}3 \\
(10)\end{array}$ & 78.33 & $\begin{array}{c}6 \\
(20)\end{array}$ & $\begin{array}{c}4 \\
(13.33)\end{array}$ & $\begin{array}{c}20 \\
(66.66)\end{array}$ & 18 \\
\hline 7 & saplings plantation & $\begin{array}{c}20 \\
(66.66)\end{array}$ & $\begin{array}{c}6 \\
(20)\end{array}$ & $\begin{array}{c}4 \\
(13.33)\end{array}$ & 76.66 & $\begin{array}{c}15 \\
(50)\end{array}$ & $\begin{array}{c}6 \\
(20)\end{array}$ & $\begin{array}{c}9 \\
(30)\end{array}$ & 60 \\
\hline 8 & Plantation distance & $\begin{array}{c}23 \\
(76.66)\end{array}$ & $\begin{array}{c}7 \\
(23.33)\end{array}$ & 0 & 88.33 & $\begin{array}{c}9 \\
(30)\end{array}$ & $\begin{array}{c}10 \\
(33.33)\end{array}$ & $\begin{array}{c}11 \\
(36.66)\end{array}$ & 47 \\
\hline 9 & Irrigation schedule & $\begin{array}{c}14 \\
(46.66)\end{array}$ & $\begin{array}{c}8 \\
(26.66)\end{array}$ & $\begin{array}{c}8 \\
(26.66)\end{array}$ & 60 & $\begin{array}{c}5 \\
(16.66)\end{array}$ & $\begin{array}{c}9 \\
(30)\end{array}$ & $\begin{array}{c}16 \\
(53.33)\end{array}$ & 32 \\
\hline 10 & $\begin{array}{l}\text { Method of manure } \\
\& \quad \text { fertilizer } \\
\text { application }\end{array}$ & $\begin{array}{c}22 \\
(73.33)\end{array}$ & $\begin{array}{c}6 \\
(20)\end{array}$ & $\begin{array}{c}2 \\
(6.66)\end{array}$ & 83.33 & $\begin{array}{c}10 \\
(33.33)\end{array}$ & $\begin{array}{c}16 \\
(53.33)\end{array}$ & $\begin{array}{c}4 \\
(13.33)\end{array}$ & 60 \\
\hline 11 & $\begin{array}{l}\text { Dose of manure \& } \\
\text { fertilizer }\end{array}$ & $\begin{array}{c}22 \\
(73.33)\end{array}$ & $\begin{array}{c}5 \\
(16.66)\end{array}$ & $\begin{array}{c}3 \\
(10)\end{array}$ & 81.66 & $\begin{array}{c}10 \\
(33.33)\end{array}$ & $\begin{array}{c}10 \\
(33.33)\end{array}$ & $\begin{array}{c}10 \\
(33.33)\end{array}$ & 50 \\
\hline 12 & Training \&Pruning & $\begin{array}{c}27 \\
(90)\end{array}$ & $\begin{array}{c}3 \\
(10)\end{array}$ & 0 & 93 & $\begin{array}{c}12 \\
(40)\end{array}$ & $\begin{array}{c}10 \\
(33.33)\end{array}$ & $\begin{array}{c}8 \\
(26.66)\end{array}$ & 57 \\
\hline 13 & Insecticides & $\begin{array}{c}24 \\
(80)\end{array}$ & $\begin{array}{c}6 \\
(20)\end{array}$ & 0 & 90 & $\begin{array}{c}12 \\
(40)\end{array}$ & $\begin{array}{c}9 \\
(30)\end{array}$ & $\begin{array}{c}9 \\
(30)\end{array}$ & 55 \\
\hline 14 & Pesticides & $\begin{array}{c}21 \\
(70) \\
\end{array}$ & $\begin{array}{c}9 \\
(30) \\
\end{array}$ & 0 & 85 & $\begin{array}{c}12 \\
(40)\end{array}$ & $\begin{array}{c}8 \\
(26.66)\end{array}$ & $\begin{array}{c}10 \\
(33.33)\end{array}$ & 53 \\
\hline 15 & Grading of fruits & $\begin{array}{c}30 \\
(100)\end{array}$ & 0 & 0 & 100 & $\begin{array}{c}10 \\
(33.33)\end{array}$ & $\begin{array}{c}8 \\
(26.66)\end{array}$ & $\begin{array}{c}12 \\
(40)\end{array}$ & 47 \\
\hline 16 & Packing of fruits & $\begin{array}{c}22 \\
(73.33)\end{array}$ & $\begin{array}{c}6 \\
(20)\end{array}$ & $\begin{array}{c}2 \\
(6.66)\end{array}$ & 83.33 & $\begin{array}{c}12 \\
(40)\end{array}$ & $\begin{array}{c}11 \\
(36.66)\end{array}$ & $\begin{array}{c}7 \\
(23.33)\end{array}$ & 58 \\
\hline 17 & Place of selling & $\begin{array}{c}30 \\
(100)\end{array}$ & 0 & 0 & 100 & $\begin{array}{c}18 \\
(60)\end{array}$ & $\begin{array}{c}9 \\
(30)\end{array}$ & $\begin{array}{c}3 \\
(10)\end{array}$ & 75 \\
\hline & Over all & $\begin{array}{c}30 \\
(100) \\
\end{array}$ & $\mathbf{0}$ & $\mathbf{0}$ & 87.15 & $\mathbf{0}$ & $\begin{array}{c}29 \\
(96.66)\end{array}$ & $\begin{array}{c}1 \\
(3.33)\end{array}$ & 52.35 \\
\hline
\end{tabular}


Adoption of Horticulture Development service was found to be high among beneficiaries with 87.15 MPS and in the nonbeneficiaries medium with 52.35 MPS. This is also evident from the distribution of respondents, as all the beneficiaries were in high adoption category while majority of the non-beneficiaries $(96.66 \%)$ were in medium adoption category.

Adoption of Aonla cultivation practices reflects that beneficiaries had high extent of adoption in all the components except irrigation schedule with medium adoption (Jitarwal and Sharam, 2007). High adoption components were variety grown, soil use for cultivation, methods of propagation, sowing time, pit size, manures and fertilizers to be filled in pits, plantation month for saplings, planting distance manure and fertilizers dose, training and pruning, insecticides, pesticides, grading of fruits, packing and selling of produce as the MPSs were above 76.66 reflecting high adoption. In all these components of aonla cultivation, 63.33 - 100 per cent of the beneficiaries were in high adoption category. In irrigation schedule, medium extent of adoption was found among beneficiaries with MPS 60 also depicted in distribution that is 46.66 per cent beneficiaries were in high adoption category, 26.66 per cent beneficiaries were in medium as well as low adoption categories. Regarding adoption of aonla practices by non-beneficiaries it can be seen from the data in Table 2 that high extent of adoption was found in sowing seeds and selling of produce with MPS 72 and 75 respectively. Further 60 per cent of nonbeneficiaries were in high extent of adoption in these components of aonla cultivation (Meena et al., 2009).

The medium extent of adoption was found for aonla cultivation among non-beneficiaries in the component high yielding variety, soil use, methods for propogation, pit size, saplings plantation, planting distance, manure and fertilizers application, dose of manure and fertilizers application, training and pruning, insects control measures, pesticides, grading and packing as the MPS ranging $38-60$. The categorization of respondents also depicts that 16.66 - 53.33 per cent of the non-beneficiaries have adopted the aonla cultivation practices to medium extent. In two components, namely quantity of manures and fertilizers and irrigation schedule, non-beneficiaries had low adoption as indicated by low MPS i.e. 18 and 32 respectively. Accordingly majority of the respondents (53.33 - 66.66\%) were also found in poor adoption category (Prasad et al., 2013).

Beneficiaries of Horticulture Development Programme adopted improved practices of aonla cultivation to a high extent as compared to non-beneficiaries. The reason may be as they are beneficiaries and getting raw material free of cost and various other benefits too, so they were adopting the practices.

According to the study findings it can be concluded that, majority of the beneficiaries possessed good or average knowledge and non-beneficiaries possessed average or poor knowledge in Agricultural Services viz. Horticulture Development and Development of whole (Agriculture) Tribal Villages. Adoption of Aonla cultivation practices reflects that beneficiaries had high extent of adoption in all the components. Regarding improvement in quality of life the beneficiaries of each Horticulture Development have improved significantly.

\section{References}

Gondalia, V.K. and Patel, G.N. 2007. An Economic Evaluation of Investment on Aonla (Emblica officinalis G.) in Gujarat. Agricultural Economics Research Review 20: 385-394 
Jatana, R. and Waldia, S. 2009. Tribal Development Programmes. Mahamaya Publishing House, New Delhi. pp: 14, $46,82,83,109-110$ and 120-121.

Jitarwal, R. C. and Sharam, N. K. 2007. Impact of Drip Irrigation Technology among Farmers in Jaipur Region of Rajasthan. Indian Research Journal of Extension Education 7: 88-89.

Meena, S. R., More, T. A., Singh, D. and Singh, I. S. 2009. Arid Vegetable
Production Potential and Income Generation. Indian Research Journal of Extension Education. 9: 72-75.

Prasad, R., Singh, A.K., Singh, L. and Singh, A. 2013. Economics of Goat Farming under Traditional low Input Production System in Uttar Pradesh. Journal of Community Mobilization and Sustainable Development, 8: 09-13.

\section{How to cite this article:}

Sonali Sharma, Snehlata Maheshwari, Rajshree Upadhyay, Bhupendra Upadhyay and Sain, H.R. 2019. Impact of Horticulture Development of Tribal Area Development Programme on Tribals of Udaipur District, India. Int.J.Curr.Microbiol.App.Sci. 8(05): 2377-2383.

doi: https://doi.org/10.20546/ijcmas.2019.805.281 